\title{
STRUCTURED SETTLEMENTS AS STRUCTURES OF RIGHTS
}

\author{
Henry E. Smith*
}

$\mathrm{W}$

$\mathrm{E}$ are all used to thinking about law in terms of the primary rights and duties that obtain in the world at large. One has a right against everyone else not to be punched in the nose or to be run over by a negligent driver. Once these primary rights are violated, a second set of rights and duties can arise out of a judgment or settlement. The victim now has a right to compensation from the tortfeasor. It is tempting to think that there is nothing interesting left to say. A judgment or settlement paid by the tortfeasor to the victim will compensate the victim according to the size of the damages in present value terms and will deter potential tortfeasors in the same proportion. Whether a settlement is paid in a lump sum or periodically should not matter because it is the amount paid that impacts the goals of tort law.

This picture is, as Professor Ellen Pryor's Article in this Symposium ably demonstrates, far from adequate. ${ }^{1}$ How settlements are structured does impact the goals of deterrence and compensation, and lump-sum or "stretched-out" settlements are not equivalent for all purposes, even if they are equal in present value terms. In a lump-sum damage award, the defendant pays the damages to the plaintiff all at once, usually some time shortly after the settlement or judgment. In the three stretched-out methods of damage payout-structured settlements, settlement trusts, and periodic payments mandated by statute-the plaintiff does not receive all of the money up front, but rather in multiple payments over some period of time (measured by a fixed number of years, or the plaintiff's life, or some combination thereof). The stretching out of the payments is meant to constrain plaintiff decisionmaking over consumption of the damage award and so involves adding higher-order decisions that constrain plaintiff's consumption decisions. All of these methods involve the plaintiff and others constraining the decisions of

${ }^{*}$ Professor, Yale Law School. A.B., 1986, Harvard College; Ph.D. (Linguistics), 1992, Stanford University; J.D., 1996, Yale University. E-mail: henry.smith@yale.edu.

${ }^{1}$ Ellen S. Pryor, After the Judgment, 88 Va. L. Rev. 1757 (2002). 
the future plaintiff. (Under a lump sum, the plaintiff is free to choose what to do with the money at any time, which, if consumed, will constrain future plaintiff choice.) If one thinks of the plaintiff as a succession of selves, any of the stretched out methods of paying damages involves an earlier stage of the plaintiff, a judge, or others deciding how future stages of the plaintiff will decide on consumption.

Where the three stretched out methods differ is in how this higher-order decisionmaking happens, in particular how many levels of higher-order decisionmaking can be identified. The most articulated mechanism is the settlement trust in which the defendant and others decide that the damage award will be used to fund a trust. Under the settlement trust, the trustee will pay out according to the plaintiff's needs as defined in the trust (for example, basic living expenses and medical care, but not gambling). The settlement trust can provide that the trustee will follow certain rules for payout or exercise some greater degree of discretion. If so, we have three levels of decisionmaking: Various actors set up the trust and decide how someone (the trustee) will decide on how the future stages of the plaintiff will decide on using the damages.

Structured settlements and periodic payment schemes differ from settlement trusts by leaving out the intermediary decisionmaker, but they differ from each other with respect to who the toplevel decisionmaker is. In a structured settlement, the plaintiff and others decide to set up the schedule of payments, which are then automatic. The plaintiff is more or less involved in this decision and to that extent she is exercising self-paternalism directly over her future selves. Although empirical evidence is thin, there is a fear that many plaintiffs will squander a lump-sum settlement and wind up with insufficient funds for basic needs and medical care or might wind up overrelying on publicly funded programs. ${ }^{2}$

In the periodic payment scheme, a statute directs a judge to set up an extended schedule for paying out damages under certain conditions (as with the passage of time or with the advent of medical bills). Although preventing bad decisionmaking by plaintiffs over use of lump-sum damages has occasionally been advanced as

\footnotetext{
${ }^{2}$ See id. at $1779-80$ for a summary of the empirical evidence. On the tax subsidy and the legislative history surrounding it, see infra notes 26-34 and accompanying text.
} 
a justification for mandatory periodic payments, ${ }^{3}$ periodic payment statutes were aimed more at reducing the value of suits and possibly reflect a concern about false and inflated claims; by not disbursing damages until plaintiff's future medical condition really does turn out to require expensive care, the periodic payment scheme is supposed to reduce false claims. ${ }^{4}$ This wait-and-see feature of mandated periodic payments has not been shown to have a large impact on the severity of claims, but, when periodic payment is mandatory, it does reduce plaintiff choice. ${ }^{5}$ I will focus on the subsidized self-paternalism that is more characteristic of the more voluntary structured settlement and settlement trust devices. In any event, with mandatory periodic payments, again, there is no intermediatelevel decisionmaker like the trustee. Here, the top-level decisionmaker is not the plaintiff but rather the judge, as constrained by the legislature.

Thus, these three methods of stretched-out payments differ in the number of levels of higher-order decisionmaking-decisions about decisions-and differ in who makes these higher-order decisions. Professor Pryor points out that structured settlements raise many questions about plaintiffs' ability to choose-questions that are related to but distinct from those involved in whether to appoint a guardian or a guardian ad litem. ${ }^{6}$ In this Essay, I will argue that many of the unique characteristics and problems with structured settlements reflect the articulation of multiple levels of delegated decisionmaking. Once we recognize the multi-tiered nature of the decisionmaking in setting up structured settlements, the tax and other legal advantages of the structured settlement can be seen as reflecting a policy of promoting self-paternalism in the face of moral hazard.

\footnotetext{
${ }^{3}$ See Roger C. Henderson, Designing a Responsible Periodic-Payment System for Tort Awards: Arizona Enacts a Prototype, 32 Ariz. L. Rev. 21, 31-32 (1990).

${ }^{4}$ Mandatory periodic payments were one aspect of 1970 s tort reform, which also included damage caps, abolition of the collateral source rule, alternative dispute resolution provisions, and contingent fee limitations. See Glen O. Robinson, The Medical Malpractice Crisis of the 1970's: A Retrospective, 49 Law \& Contemp. Probs. 5, 22-27 (1986).

${ }^{5}$ Professor Patricia Danzon found that of various tort reform provisions, only damage caps and abolition of the collateral source rule were associated with a significant reduction in the severity of medical malpractice claims. Patricia M. Danzon, Medical Malpractice: Theory, Evidence, and Public Policy 78 (1985).

${ }^{6}$ See generally Pryor, supra note 1.
} 
Part I will articulate a framework for analyzing methods of paying damages in terms of higher-order decisionmaking and will point out the similarities to other uses of delegating or constraining decisions in spendthrift trusts and in entitlement structures more generally. Part II will examine how current tax and bankruptcy law favor structured settlements, reflecting an apparent policy of subsidizing self-paternalism on the part of plaintiffs. These higher-order self-paternalistic decisions are supposed to constrain the lowerlevel consumption decisions by later stages of the plaintiff. Part III will turn to the question of how current law does or does not give effect to the constraints imposed by the higher-level decision to space out payments of damages. Finally, Part IV will point out some conflicts between effecting self-paternalism and other goals, which have led to an undermining of the effectiveness of structured settlements in encouraging plaintiff self-paternalism.

\section{THREE LEVELS OF DECISIONMAKING}

In the settlement trust, the structured settlement, and related devices, three levels of decisionmaking are required. First, there is the choice of how the money will be used on a day-to-day basis. Will the money be used for doctor's bills, other bills, gambled away, and so on? Second, there is a second-order choice about the consumption choice: Who will choose (and when) how to use the money? In some cases, a trustee will decide when to pay out to the plaintiff, leaving the day-to-day choice to the plaintiff-beneficiary. In other cases, the distinction between these two choices is less apparent: With a lump sum, the plaintiff will choose now whether to spend or save, in effect choosing whether to delegate the decision to a later stage of herself. Third, there is the choice of who makes the second-order choice: Who will make the choice of who makes the choice of how to use the money? For example, the judge (or the plaintiff) could decide to set up a trust so that a trustee will make the choice of when the plaintiff can make the everyday consumption choices. In this Part, I first illustrate higher-order decisionmaking and delegation in an analogous area-the spendthrift trust. Then I argue that higher-order decisionmaking is a more or less apparent feature of entitlement and liability structures that respond to different distributions of information and other decisionmaking ability. 
That a settlement trust is an alternative to a structured settlement highlights the aspect of delegated decisionmaking that is familiar in the area of trusts. One type of trust that bears an especially close resemblance to settlement trusts (and structured settlements) is the spendthrift trust. A spendthrift trust is one in which a settlor creates the trust and gives the trustee instructions about paying out to the beneficiary; the trustee can be directed to pay for needs such as maintenance and education only as these needs arise, or the trustee can be given discretion to determine how much (including whether) to pay out to the beneficiary. The beneficiary has the choice of how to use each payment only after it is received, but does not have an interest that can be attached by creditors while the funds are still in the trust. ${ }^{8}$ The beneficial interest is designed not to be assignable or otherwise subject to anticipation and is not part of the estate of a beneficiary in bankruptcy. Settlors find the spendthrift trust particularly attractive if they worry about the ability of beneficiaries to manage money rather than fritter it away. Spendthrift trusts in someone other than the settlor have long been permitted in the United States, despite the famous early criticisms of Professor John Chipman Gray. He objected vehemently that creditors might be deceived by the beneficiary's appearance of prosperity into lending to the beneficiary but later be unable to collect on a bad debt by attaching the trust. ${ }^{10}$ (Chasing the payments as they are made would be prohibitively difficult.)

${ }^{7}$ George T. Bogert, Trusts $\$ \S 41-42$ (6th ed. 1987) (discussing discretionary trusts and support trusts).

${ }^{8}$ See George Gleason Bogert \& George Taylor Bogert, The Law of Trusts and Trustees $\$ 221$ (rev. 2d ed., repl. vol. 1992); Austin Wakeman Scott \& William Franklin Fratcher, The Law of Trusts $\$ \S 151-155$ (4th ed. 1987).

${ }^{9}$ See Scott \& Fratcher, supra note $8, \S 152.2$, at 108 .

${ }^{10}$ Professor Gray believed that spendthrift trusts were a potential disaster:

That ... men not paying their debts should live in luxury on inherited wealth, are doctrines as undemocratic as can well be conceived. They are suited to the times in which ... the law was administered in the interest of rich and powerful families. The general introduction of spendthrift trusts would be to form a privileged class, who could indulge in every speculation, could practise every fraud, and yet, provided they kept on the safe side of the criminal law, could roll in wealth. They would be an aristocracy, though certainly the most contemptible aristocracy with which a country was ever cursed.

John Chipman Gray, Restraints on the Alienation of Property 246-47 (Boston, Boston Book Co. 1895). 
Whether such false appearances were ever a major problem, they are not likely to be a major one in our era of credit checks and digital information technology, ${ }^{11}$ and Professor Gray's disgust at the idea of the idle plutocracy that he feared spendthrift trusts would promote is not much of a concern in the tort settlement context. ${ }^{12}$ More pressing problems are whether certain classes of claims against the beneficiary, such as those for child support, alimony, and by victims of the beneficiary's torts, should receive the spendthrift protection; many states do not extend the anti-creditor protections of a spendthrift trust to these sorts of claims. ${ }^{13}$ Thus, in the somewhat analogous situation of a plaintiff who is the beneficiary of a settlement trust or a structured settlement, future tort creditors of the plaintiff might have a stronger claim on the trust's assets or the annuity than would voluntary creditors. As we will see, another question is the plaintiff's role in setting up a settlement trust or a structured settlement. The greater the plaintiff's role, the more the plaintiff might - unpersuasively, I argue — be analogized to the settlor of a spendthrift trust. Traditionally, spendthrift trusts cannot be used to shield the settlor's own assets from creditors; most states do not extend protection to self-settled spendthrift trusts. ${ }^{14}$ More recently, however, even such self-settled spendthrift trusts have been permitted by legislation in Alaska and Delaware. ${ }^{15}$

The settlement trust, one of the three methods of stretching out damage payments, has spendthrift-like limits on payouts for reasons similar to those that appeal to settlors of spendthrift trusts. The structured settlement, another of the three stretched-out damage payout methods, is similar to the spendthrift trust except that

\footnotetext{
${ }^{11}$ See Adam J. Hirsch, Spendthrift Trusts and Public Policy: Economic and Cognitive Perspectives, 73 Wash. U. L.Q. 1, 64-65 (1995).

${ }^{12}$ Gray, supra note 10 , at vi ("One of the worst results of spendthrift trusts ... is the encouragement it gives to a plutocracy, and to the accumulation of a great fortune in a single hand, through the power it affords to rich men to assure the undisturbed possession of wealth to their children, however weak or wicked they may be.").

${ }^{1.3}$ See Bogert \& Bogert, supra note $8, \S 224$, at 456-59.

${ }^{14}$ See Scott \& Fratcher, supra note $8, \S 156$, at $164-65$.

${ }^{15}$ See Alaska Stat. $\$ \S 13.36 .035,13.36 .045,13.36 .310,13.36 .390,34.40 .110$ (Michie 2000); Qualified Dispositions in Trust Act, Del. Code Ann. tit. 12, §§ 3570-3576 (2001). Controversy surrounds the question of whether these self-settled spendthrift trusts can be brought by creditors into a beneficiary's bankruptcy estate. See, e.g., Michael Sjuggerud, Defeating the Self-Settled Spendthrift Trust in Bankruptcy, 28 Fla. St. U. L. Rev. 977 (2001).
} 
the schedule of payments is more mechanical, making the trustee's role fall out of the picture. The person setting up the structured settlement (the analog of the settlor of a trust) is, depending on the case, in part the plaintiff-beneficiary who is exercising some selfpaternalism. But unlike in the typical self-settled spendthrift trust, the occasion for the trust and the funding will come not from the plaintiff-beneficiary but from the defendant (in satisfaction of the tort claim, to be sure). As Professor Pryor's Article emphasizes, a major issue in this area is even the extent of plaintiff decisionmaking in choosing a trust or a structure, as opposed to a lump sum. ${ }^{16}$

Postjudgment rights and duties share this feature of layered decisionmaking with other rights structures, but exhibit more of these levels. In general, structures of rights and liabilities can be thought of in terms of delegated decisionmaking. This is most familiar from torts where there is an argument for placing liability on the "cheapest cost avoider," the party who can gather and act on information about accident avoidance. ${ }^{17}$ By using strict liability and charging external harm to such a party, that party rather than the court can engage in the choice between incurring prevention costs or accident costs (because the latter will equal expected damages). Decisions are delegated to the liable party, and the liable party is in effect the residual claimant of the activity: The benefits as well as the costs of finding a new, cheaper method of prevention accrue to the liable party. ${ }^{18}$ By contrast, a reasonable person standard in-

\footnotetext{
${ }^{16}$ See Pryor, supra note 1 , at 1767-92.

${ }^{17}$ See Guido Calabresi, The Costs of Accidents: A Legal and Economic Analysis 135 n.73 (1970); Guido Calabresi \& Jon T. Hirschoff, Toward a Test for Strict Liability in Torts, 81 Yale L.J. 1055, 1057-58 (1972); see also Ian Ayres \& Paul M. Goldbart, Optimal Delegation and Decoupling in the Design of Liability Rules, 100 Mich. L. Rev. 1 (2001) (analyzing single- and dual-chooser allocations to determine the most likely conditions to achieve allocative equilibrium); James E. Krier \& Stewart J. Schwab, Property Rules and Liability Rules: The Cathedral in Another Light, 70 N.Y.U. L. Rev. 440, 474 (1995) ("[N]o liability rule can take advantage of both the best chooser and the lowest assessment costs.").

${ }^{18}$ See, e.g., Roland N. McKean, Products Liability: Implications of Some Changing Property Rights, 84 Q.J. Econ. 611 (1970); Roland N. McKean, Products Liability: Trends and Implications, 38 U. Chi. L. Rev. 3 (1970); see also Yoram Barzel, Economic Analysis of Property Rights 3-4 (2d ed. 1997) (identifying economic notion of property rights with residual claimancy); Eugene F. Fama \& Michael C. Jensen, Agency Problems and Residual Claims, 26 J.L. \& Econ. 327, 328 (1983) (defining "residual claim").
} 
volves less delegation by requiring the fact finder (jury or judge) to evaluate potential precautionary measures.

A delegation of even greater scope occurs with rights that we think of as property. By making someone the owner of an asset, we allow that actor (the "owner") to compare the potential uses of the asset, including transfer at whatever prices are being offered. ${ }^{19}$ Where the set of uses is open-ended and difficult for the courts and other officials to evaluate, property rights allow for a high degree of decentralized decisionmaking. Much of the law of property rests on a foundation of rules that use very rough proxies that delegate decisions to owners: A boundary, literal or metaphorical, is a proxy for a wide range of uses, among which the owner may choose. The owner is the gatekeeper of the asset and officials need only worry about defending the proxies-such as presence over a boundary line in trespass - that demarcate the scope of the gatekeeper's rights. ${ }^{20}$ The owner can then contract with others for access to the asset. Within the constraints on the right to exclude-such as the absence of a right to exclude emergency personnel-courts protect the owner in her property, and the owner thus has a sphere of decisionmaking within which she is answerable to herself. This sphere of autonomous decisionmaking for the owner has been particularly emphasized in libertarian theories of property. ${ }^{21}$

\footnotetext{
${ }^{19}$ Henry E. Smith, Execution versus Governance: Two Strategies for Delineating Property Rights, 31 J. Legal Stud. (forthcoming 2002).

${ }^{20}$ J.E. Penner, The Idea of Property in Law 74-75 (1997) (using gatekeeper metaphor for property); Thomas W. Merrill, Property and the Right to Exclude, 77 Neb. L. Rev. 730 (1998) (adopting the gatekeeper metaphor to explain the distinctive nature of property rights); see also, e.g., Jeremy Waldron, The Right to Private Property 39 (1988) ("In a private property system, a rule is laid down that, in the case of each object, the individual person whose name is attached to that object is to determine how the object shall be used and by whom. His decision is to be upheld by the society as final.").

${ }^{21}$ See, e.g., Randy E. Barnett, The Structure of Liberty 139-42, 238 (1998) (discussing benefits flowing from the sphere of autonomy secured by property rights); Milton Friedman, Capitalism and Freedom 7-32 (1962) (arguing that economic arrangements based on private property are a necessary condition for a free society); Robert Nozick, Anarachy, State, and Utopia 149-231 (1974) (sketching an historical entitlement theory based on principles of justice in original acquisition of holdings, of transfer of holdings, and of rectification of injustice in holdings); Richard Pipes, Property and Freedom 118-20 (1999) (arguing for a close historical relationship between private property and notions of freedom). But see, e.g., Waldron, supra note 20, at 290 322 (1988) (discussing the relationship between private property and various types of
} 
Further decisions to modify the basic exclusionary regime occur through self- or judicially-enforced contracts or through "fine tuning" doctrines such as those of nuisance or regulation. ${ }^{22}$ As in the case of the reasonable-person standard noted above, nuisance involves less delegation to owners than does trespass because officials (here judges) make decisions over proper use directly. ${ }^{23}$ This decreased delegation would tend to happen when the stakes are high enough, and alternatives to official decisionmaking (such as private contracting) are comparatively costly enough to overcome the advantages of simple decisions delegated to owners. ${ }^{24}$

What many of these cases of primary rights share is that the court or legislature is making a decision that is second-order: choosing the best chooser. In structured settlements and other post-judgment rights structures, however, it is useful to think of at least three levels of decisions. The three levels are easiest to separate where different actors are making decisions at different levels. Among the three devices with which we are concerned, this is likeliest to be true in a settlement trust. Here the court, aided by the parties and any guardians, chooses a trustee who will then choose when to disburse money to the plaintiff who will then choose how to use it. ${ }^{25}$ How a choice is made at a higher level can constrain choice at a lower level; sometimes that is the whole point. Thus, for example, the trustee in a spendthrift-type arrangement will choose

liberty); G.A. Cohen et al., How Patterns Preserve Liberty, 11 Erkenntnis 5, 21 (1977) (arguing that Nozick's libertarian capitalism "sacrifices liberty to capitalism").

${ }^{22}$ See Thomas W. Merrill \& Henry E. Smith, What Happened to Property in Law and Economics?, 111 Yale L.J. 357, 394-97 (2001); see also Carol M. Rose, Rethinking Environmental Controls: Management Strategies for Common Resources, 1991 Duke L.J. 1, 9-36 (delineating and comparing the cost of various strategies for managing common environmental resources).

${ }^{23}$ Thomas W. Merrill, Trespass, Nuisance, and the Costs of Determining Property Rights, 14 J. Legal Stud. 13 (1985) (distinguishing mechanical and judgmental rules in trespass and nuisance, respectively, and attributing difference to higher levels of transaction costs in nuisance-type situations).

${ }^{24}$ Merrill \& Smith, supra note 22, at 395-97 (analyzing nuisance as a system of use governance involving greater delineation and communication costs than trespass and explaining additional features of nuisance law not reflecting traditional transaction costs); see also Smith, supra note 19 (proposing framework based on exclusion and governance).

${ }^{25}$ If the payment made in a stretched-out payment method might be saved by the (later-stage) plaintiff or put into a new trust, there can be even more levels of decisionmaking. 
to give less choice to earlier stages of the beneficiary than if disbursement were all at once. There may be certain things that the beneficiary over time cannot choose (certain investments, gambling, and so on) because the trustee's (or the settlor's) choice makes it prohibitively costly.

\section{SubSidizing HigheR-ORdER DECISIONS}

Distinguishing the three levels of decisions will allow an explanation of the favorable treatment of structured settlements in tax and bankruptcy. The favorable tax treatment subsidizes plaintiffs' selfpaternalistic, higher-order choice to forego lower-order choices later on.

Consider the tax advantage to structured settlements. This tax advantage goes beyond the favorable tax treatment of lump-sum tort awards. In the general case, nonpunitive awards to personal injury plaintiffs are not taxable. ${ }^{26}$ But in the case of a structured settlement, even delayed payments are entirely tax-free. ${ }^{27}$ This advantage goes beyond the nontaxation of a lump sum, because the proceeds of an invested lump sum are taxed, whereas a structured settlement can build up tax-free prior to withdrawal. The ostensible policy behind the tax break is to avoid situations in which plaintiffs squander large judgments and then wind up without sufficient resources to support themselves and their dependents or to pay for needed medical care. ${ }^{28}$ The public has some stake in not seeing plaintiffs exhaust a lump sum, particularly where the government will be expected then to provide further support and medical care. ${ }^{29}$ Congress can be seen as making a bargain on behalf of the public with the plaintiff that in return for the lack of flexibility and choice at the first-order level of decisionmaking, the plaintiff can enjoy an additional advantage of tax-free build-up. As long as defendants do

\footnotetext{
${ }^{26}$ I.R.C. $\S 104(\mathrm{a})(2)(2002)$.

${ }^{27}$ Id. $§ 130$.

${ }^{28}$ Interestingly, legislative history gave no clue as to the reason for the exclusion of the build-up in a structured settlement until a Joint Committee Report in 1999, which noted that the possibility of moral hazard in exhausting a lump-sum recovery and relying on government programs may justify a "subsidy" to encourage plaintiffs or their guardians to choose a structured settlement that would lessen this possibility. Staff of Joint Comm. on Taxation, 106th Cong., Tax Treatment of Structured Settlement Arrangements 7 (Comm. Print 1999).

${ }^{29}$ Id.
} 
not manage to appropriate this benefit for themselves (which this Essay addresses later), the plaintiff's lack of autonomy in consumption is the quid for the tax-break quo. ${ }^{30}$

The structured settlement is not the only area in which a tax preference is given where the concern is that people need extra encouragement to provide for their futures. Retirement saving is heavily subsidized through the Tax Code and is even coerced though Social Security. ${ }^{31}$ The strongest argument for such carrots and sticks is that people have excessively high discount rates and so will not save enough for retirement. ${ }^{32}$ Further, there may be some concern that without forced saving people will over-depend on public programs. ${ }^{33}$ Likewise with structured settlements, where a plaintiff can be regarded as multiple selves and the earlier self will not take the later one's needs sufficiently into account, society may decide to encourage the earlier self to make sure that sufficient resources are available for the later self. ${ }^{34}$ Such a decision could re-

${ }^{30}$ As a carrot, the tax break is more favorable to plaintiffs' autonomy than other
mandatory restrictions on freedom of contract such as the unconscionability doc-
trine-which may similarly prevent people from taking moral-hazard type risks in the
presence of a public welfare system. See Eric A. Posner, Contract Law in the Welfare
State: A Defense of the Unconscionability Doctrine, Usury Laws, and Related Limi-
tations on the Freedom to Contract, 24 J. Legal Stud. 283 (1995).
${ }^{31}$ See, e.g., I.R.C. $\$ \$ 401-404,408,410-416(2002)$ (providing for favorable treat-
ment of qualified pension, profit-sharing, and stock bonus plans); see also id. $\$ 72$
$(2002)$ (providing for favorable treatment of annuities); id. $\S 101$ (2002) (providing
favorable treatment to build-up on life insurance policies and exempting mortality
gains from tax).
vidual but does nothing to ensure that each individual saves more than he would oth-
erwise or that society as a whole saves more. See Daniel Shaviro, Making Sense of
Social Security Reform $29-30$ (2000); see also Michael J. Graetz \& Jerry L. Mashaw,
True Security: Rethinking American Social Insurance $255-78$ (1999) (reviewing pro-
posed reforms for securing retirement income and protecting Social Security benefits).

${ }^{33}$ On the various types of moral hazard involved, see Shaviro, supra note 32, at 58-59.

${ }^{34}$ See Jon Elster, Ulysses and the Sirens: Studies in Rationality and Irrationality 37 (rev. ed. 1984) (discussing alternatives to self-paternalism); Russell B. Korobkin \& Thomas S. Ulen, Law and Behavioral Science: Removing the Rationality Assumption from Law and Economics, 88 Cal. L. Rev. 1051, 1119-24 (2000) (discussing the problem of dynamic inconsistency and multiple selves and noting which approaches privileging the earlier self would be consistent with rational choice theory and which would not); Richard A. Posner, Are We One Self or Multiple Selves?: Implications for Law and Public Policy, 3 Legal Theory 23 (1997) (arguing that multiple-self analy- 
flect paternalism or the moral hazard presented by relying on public programs.

The other great advantage that law bestows on structured settlements is, as already mentioned, their exemption from the claims of creditors and their probable noninclusion in the estate of a tort plaintiff who winds up in bankruptcy. ${ }^{35}$ By not being reachable in bankruptcy, the future payments in a structured settlement bear a strong resemblance to other streams of payments such as some insurance policies, beneficial interests in spendthrift trusts, and, to some extent, pensions ${ }^{36}$ For the courts, the lack of control of the person who will receive the payments is a key to finding them unreachable by creditors in bankruptcy. ${ }^{37}$ Structured settlements are exempt for similar reasons: The payments are meant for the plaintiff's needs and the plaintiff does not have ownership or other control over the payments in advance.

Again, this treatment can be seen as part of the bargain implicit in the tax subsidy for structured settlements. The subsidy purchases the plaintiff's willingness to forego freedom of disposition, and the public thereby purchases the plaintiff's greater likelihood of being provided with resources and nonreliance on public welfare programs. If so, it makes sense that this public claim might, in effect, have priority over some claims in bankruptcy. As we will see, allowing voluntary creditors access to the settlement in bankruptcy would increase the plaintiff's ability to undo the transaction; for example, a plaintiff could borrow for current consumption (gam-

sis is consistent with rational choice theory, and discussing the implications of individuals having both a more short-term oriented "child" self and a more long-term oriented "adult" self); Thomas C. Schelling, Self-Command in Practice, in Policy, and in a Theory of Rational Choice, 74 Am. Econ. Rev. (Papers \& Proc.) 1, 6-10 (1984) (noting problems of different selves and its relationship to policy choices).

${ }^{35}$ See, e.g., In re Belue, 238 B.R. 218 (S.D. Fla. 1999); In re Alexander, 227 B.R. 658, 661 (N.D. Tex. 1998).

${ }^{36}$ See 11 U.S.C. $\$ \S 522,541$ (c)(2) (2000); Restatement (Second) of Trusts $\$ \S 150-55$ (1959). In general, the question is whether state law provides anti-alienation features for a given right that would place it outside the property of the estate for purposes of Section 541 of the Bankruptcy Code. See Patterson v. Shumate, 504 U.S. 753, 758 (1992).

${ }^{37}$ See, e.g., George R. Pitts, Rights to Future Payment as Property of the Estate Under Section 541 of the Bankruptcy Code, 64 Am. Bankr. L.J. 61 (1990). For an argument that a class of assets even broader than those to which the debtor does not have present access should be unavailable to creditors in bankruptcy, see Thomas $\mathrm{H}$. Jackson, The Logic and Limits of Bankruptcy Law 260-64 (1986). 
bling or whatever), securing the debt with the expected payments. ${ }^{38}$ If the lender cannot touch the payments in bankruptcy, such transactions anticipating the payments will become more costly. Putting the settlement funds out of the reach of creditors makes it more difficult for the plaintiff to undo the structure and to thereby defeat the purpose of the subsidy of which he has taken advantage.

Not including a structured settlement in a bankrupt's estate can be viewed as an advantage or a disadvantage. Ex post, a plaintiff in bankruptcy would prefer not to lose the settlement. Before bankruptcy, a plaintiff might decide that he would like to alienate the right to the settlement payments. And, even earlier, at the time of the decision between a lump sum or a structured settlement, the plaintiff might prefer the structure even if it means losing the flexibility of alienability later on. At this earlier stage, it is not clear at all as a normative matter that structured settlements should receive the tax or special treatment in bankruptcy if the plaintiff did not give up any flexibility. Reducing the flexibility to squander funds is the point of the tax subsidy for structured settlements.

It is also instructive to push the analysis back even further and compare the plaintiff deciding on the type of settlement payout mechanism, on the one hand, with an uninjured person in otherwise similar circumstances on the other. Almost by definition, the tort victim did not choose to be injured. In this case, we might say that a sort of "realization requirement" comes into play. That is, one's body, safety, and human capital are assets one owns, which are protected by tort law. In the case of an ordinary non-self asset, selling the asset is a realization event (in the tax sense), and tax on any gain (or potential deduction of losses) happens then. Without a voluntary transaction, however, we are more reluctant to impose tax: Annual reporting and valuation may be difficult, and one may not have cash on hand to pay the tax. ${ }^{39}$ Thus in an involuntary context such as a tort recovery, the Tax Code is more generous in its

\footnotetext{
${ }^{38}$ A plaintiff in bankruptcy, however, may not be able to discharge a debt to a settlement purchaser if his intent is to defraud settlement purchasers. See In re Brooks, 248 B.R. 99 (W.D. Mich. 2000). Note that in Brooks, assignment may have been less problematic in the first place since some, but not all, of the agreements contained anti-assignment clauses. Id. at 103.

${ }^{39}$ See, e.g., Helvering v. Horst, 311 U.S. 112, 116-17 (1940); United States Dep't of the Treasury, Blueprints for Basic Tax Reform 75-76 (1977).
} 
treatment of such realizations. For example, in the case of assets like land, a tort recovery is a realization event but one gets the advantage of freely using basis against the recovery. ${ }^{40}$ In the case of personal physical injury, as mentioned, the Code does not tax compensatory awards at all.

The size of the subsidy element here depends in part on the taxability of what the tort award replaces. The nontaxation of even the build-up on the settlement is less of a subsidy to the extent that it replaces nontaxable imputed income. We can think of the self as an asset, as a stock from which a flow of services gives rise to income. This income can be imputed, as in walking one's dog or cleaning one's house, in which case there is no tax. Or the services can lead to income, for example wages, on which there will be tax. Much of a personal physical injury recovery, however, is for lost wages. $^{41}$

Whatever the size of this element of subsidy in the tax treatment of structured settlements, the comparison to the situation of a noninjured person helps explain the lack of alienability of the structured settlements. A noninjured person has the intact asset or "stock" from which the flow is expected, but in many cases the value of that stock is hard to measure. For this reason, the person may be able to borrow less against the value of these future flows. Nor can the stock be pledged or alienated because that would conflict with our policies of a fresh start in bankruptcy, and more extreme examples raise the specter of slavery. A plaintiff with a lump sum has more ability to borrow or consume now rather than later than would the corresponding noninjured person. All else being equal, this extra liquidity is a plus, but if there are independent reasons to restrict such transactions, the plaintiff is not losing an ability that a noninjured person freely enjoys.

So putting all these strands together, the Tax Code offers the plaintiff a bargain in which the plaintiff gives up the extra alienabil-

\footnotetext{
${ }^{40}$ See Inaja Land Co. v. Commissioner, 9 T.C. 727 (1947), acq., 1948-1 C.B. 2. In a voluntary disposition, basis must be allocated equitably between the disposed and retained portions of the property according to relative value. Treas. Reg. $\S 1.61-6(\mathrm{a})$ (2001).

${ }^{41}$ Other components of recovery, to the extent that they are allowed, may correlate with lost wages, but this might be an attempt to associate a monetary amount with lost imputed income.
} 
ity and flexibility that come with a lump sum as opposed to one's uninjured self as an asset (and perhaps loses some more flexibility over this amount), in return for a package consisting of favorable tax treatment of the build-up in the fund and protection in bankruptcy. How much flexibility a given plaintiff has foregone will depend on how easily that plaintiff could have borrowed in the uninjured state, and how costly the lack of flexibility under the structure would be is often best known by the individual plaintiff. ${ }^{42}$ For this reason and out of general respect for plaintiff autonomy, these decisions are within a sphere that is best left to plaintiffs themselves, unless serious incapacity is shown or can be presumed (as in the case of minors). Balancing the costs against the tax advantage is best done by the plaintiff as long as the plaintiff can be informed of those aspects of the decision (the tax and bankruptcy aspects) about which the plaintiff does not have an informational advantage to begin with.

\section{CONSTRAINING LOWER-LEVEL DECISIONS}

How costly it will be for a lower-level decisionmaker to evade the restrictions put in place by higher-level decisionmakers will depend on enforcement and transaction costs. As long as there is no market in income streams such as those from structured settlements and the plaintiff finds it too difficult to borrow against the stream, the plaintiff must simply wait for the funds to be disbursed. With the rise of a market in financial products, however, and factoring transactions in particular, the plaintiff may acquire the ability to undo the spendthrift aspect of the settlement. ${ }^{43}$ Financial theory indicates the size of the lump sum to which any given stream of

\footnotetext{
${ }^{42}$ One aspect of the flexibility problem is that plaintiffs opting for the structured settlement run more risk from inflation than would someone who invested a lump sum in equities (or a noninjured person receiving wages). See, e.g., Dirk Yandell, Advantages and Disadvantages of Structured Settlements, 5 J. Legal Econ. 71, 73 (1995). Recently this has been partially alleviated through shortening the duration of the structure, or through use of a variable income annuity. See Joseph Kelner \& Robert S. Kelner, Variable Income Annuity Structured Settlements, N.Y. L.J., June 27, 2000, at 3, 3-4.

${ }^{43}$ See, e.g., Gregory Scott Crespi, Selling Structured Settlements: The Uncertain Effect of Anti-Assignment Clauses, 28 Pepp. L. Rev. 787 (2001); Leo Andrada, Note, Structured Settlements: The Assignability Problem, 9 S. Cal. Interdisc. L.J. 465 (2000).
} 
income would be equivalent in terms of present discounted value, and often it is only transaction costs that are the main barrier to easy conversion between the one and the other. ${ }^{44}$ But with the development of financial and related markets, transaction costs are a decreasing barrier to the translation from income stream to lump sum. The alternative to relying on transaction costs is direct enforcement.

Relying on transaction costs to prevent undesired alienation is becoming generally less possible. Developed markets in financial products tend to break down the distinction between fixed and contingent payments. Thus, the tax law has long made crucial distinctions between fixed and contingent payments, ${ }^{45}$ but here too as transaction costs have lowered and markets in financial products have developed, the form of a payment as fixed or contingent is more manipulable and difficult to classify and police for tax purposes. ${ }^{46}$ Indeed, in both tax and property law, transaction costs themselves can sometimes be regarded as a potential method of enforcement: If frictions prevent undesired adjustment or actions on the part of the regulated actor, the law need not directly act to prevent those actions. ${ }^{47}$ Property law sometimes uses a combination of direct enforcement and "natural" frictions to prevent opportunistic behavior. ${ }^{48}$ For example, copyright needed less enforcement in an era in which copying itself was costly and the copy less useful than an original (for example, photocopying an entire book); with

\footnotetext{
${ }^{44}$ See, e.g., Yakov Amihud \& Haim Mendelson, A New Approach to the Regulation of Trading Across Securities Markets, 71 N.Y.U. L. Rev. 1411, 1427-30 (1996) (reporting empirical studies of significant impact of discounted anticipated cost of trading of stocks on their prices); William F. Landsea \& David L. Roberts, Inflation and the Present Value of Future Economic Damages, 37 U. Miami L. Rev. 93, 99-102 (1982) (explaining the difficulties in calculating present values for lump-sum awards and noting the costliness of expert testimony).

${ }^{45}$ Alvin C. Warren, Jr., Financial Contract Innovation and Income Tax Policy, 107 Harv. L. Rev. 460, 465-73 (1993).

${ }^{46}$ See id. at 473 (summarizing the challenge to the income tax that full contractual implementation of financial equivalences would pose).

${ }^{+7}$ See, e.g., David M. Schizer, Frictions as a Constraint on Tax Planning, 101 Colum. L. Rev. 1312 (2001) (discussing how tax systems can rely on some transaction costs as barriers to undesirable tax planning).

${ }^{48}$ Henry E. Smith, Semicommon Property Rights and Scattering in the Open Fields, 29 J. Legal Stud. 131, 131-54, 161-69 (2000).
} 
the rise of digital technology, if copying is to be prevented, the law can no longer depend on these extralegal frictions to do the job. ${ }^{49}$

Similarly, with structured settlements, the ability of plaintiffs to precommit to the structure can no longer depend as much as it has on the frictions involved in undoing the structure. Thus, as the possibility of borrowing against, selling, or otherwise anticipating structured settlements becomes more plausible, either the promotion of structured settlements must find a new justification or measures must be taken to ensure that the subsidized self-paternalism in the structured settlement is carried through. Such measures could include more certain enforcement of anti-assignment clauses or taxation of factoring transactions. Less mandatorily, one could give plaintiffs a choice between assignable and nonassignable structured settlements. If the assignment is inconsistent with the policy behind the tax break and bankruptcy exemption for structured settlements, then the menu could be (1) a tax- and bankruptcy-favored non-assignable structured settlement or (2) an assignable structured settlement without the tax and bankruptcy advantages.

\section{CONFLICTS BETWEEN GoALS}

The structure of rights in structured settlements involves multitiered delegation in which the plaintiff trades some lower-level freedom for a subsidy. This multi-tier analysis allows us to see where the goals of the law of structured settlements sometimes conflict and to point to some possible resolutions.

Least surprisingly, there is an (apparent) paradox of freedom in structured settlements. In this regard, structured settlements are no different from other situations in which an actor at time one binds her future selves. In particular, structured settlements involve an element of self-paternalism often likened to the story of Ulysses

\footnotetext{
${ }^{49}$ Technology may make violation easier but may also make self-help protection easier. See, e.g., I. Trotter Hardy, Not So Different: Tangible, Intangible, Digital, and Analog Works and Their Comparison for Copyright Purposes, 26 U. Dayton L. Rev. 211, 236-37 (2001); see also David D. Friedman, Law's Order 144 (2000) (discussing the development of encryption technology to protect certain intellectual property); Kenneth W. Dam, Self-Help in the Digital Jungle, 28 J. Legal Stud. 393 (1999) (discussing the use of self-help systems to reduce the number of copyright violations).
} 
and the Sirens. ${ }^{50}$ The difference between Ulysses and the plaintiff in the structured settlement is that, so far as we know, Ulysses did not get a tax break to encourage being bound. In any event, maximizing freedom in later, lower-level decisions may not maximize freedom in earlier, higher-level decisions. Freedom includes the freedom to bind oneself (including one's later self), as is familiar from the practices of promising and contracting.

Relatedly, lowering transaction costs does not always promote contracting if there are multiple levels involved. Lowering transaction costs may make the selling or other anticipation of the structured settlement easier. But this means that the higher-level "deal" between the government and the plaintiff (or between the defendant and the plaintiff) to provide for a stream of unanticipatable payments becomes harder to make stick. Although this problem in its general form goes beyond the scope of this Essay, it is noteworthy that one of the recurring difficulties in the literature on transaction-cost economics is related to transaction costs operating on multiple levels. In a frictionless world, one might think that breach would be costless, but in a zero-transaction cost world, one should be able to create frictions frictionlessly. ${ }^{51}$ In the real, positive transaction-cost world we live in, the point remains that lowering transaction costs for one type of choice may make it more costly to implement the enforcement of a prior, higher-level choice not to allow that choice.

If these problems become large enough, we can get a situation in which promoting alienability mandatorily does not promote easy alienation. Generally, if I could not restrict the alienability of an asset I transfer, I might not be willing to part with it in the first place. Bailments and leases can be thought of as partial alienations that both depend on partial alienation (and may in some circumstances be promoted by further anti-alienation devices). In the context of structured settlements, if plaintiffs cannot alienate their

\footnotetext{
${ }^{50}$ See, e.g., Jon Elster, supra note 34, at 1-111 (discussing self-paternalism and using the story of Ulysses and the sirens as a primary illustration).

${ }^{51}$ For a dramatic example of this problem, compare Varouj A. Aivazian \& Jeffrey L. Callen, The Coase Theorem and the Empty Core, 24 J.L. \& Econ. 175 (1981) (arguing that for certain assumed values the Coase Theorem does not hold when three parties contest the use of a resource and coalitions are permitted), with R.H. Coase, The Coase Theorem and the Empty Core: A Comment, 24 J.L. \& Econ. 183 (1981) (arguing that binding contracts can prevent cycling through coalitions).
} 
ability to alienate structured settlements, the tax subsidy could become unattractive to Congress and structured settlements could conceivably lose their tax break (provided that the structured settlement industry does not manage to defend it). If the subsidy is part of a bargain between the plaintiff and the government (or the public), which the latter would not enter into unless the former agrees not to alienate, future deals of this sort may lose their attractiveness. Without knowing more empirical details of the political economy of such subsidies it is hard to say what the effect would be, but, at any rate, the point is that there is no necessary link between promotion of alienability of assets across the board and promoting structured settlements. Allowing plaintiffs to opt into anti-alienation may smooth these higher-order plaintiffgovernment "transactions" alienating the flexibility of the lump sum to create structured settlements."

Furthermore, in structured settlements, doctrines aimed at enforcing the lower-level constraints on plaintiffs can have the effect of interfering with plaintiffs' participation in and benefiting from the higher-level decisionmaking that sets up the structured settlement. Take the constructive receipt doctrine, under which a plaintiff with too much control over the resources will lose the benefits of tax-free build-up. ${ }^{53}$ The problem is that defendants can use this as a stick to make sure that plaintiffs are not very involved with setting up the structure: If the plaintiff knows the cost and details of the funding of the structure, the plaintiff might be deemed to have too much control and so lose the benefit. Thus, carrying the constructive receipt doctrine that far-and the IRS probably would

\footnotetext{
${ }^{52}$ Restraints on alienation may implicate the numerus clausus principle (requiring a fixed standard set of property forms), but trusts and possibly structured settlements may have features that keep down third-party information costs. Thomas W. Merrill \& Henry E. Smith, Optimal Standardization in the Law of Property: The Numerus Clausus Principle, 110 Yale L.J. 1 (2000); Thomas W. Merrill \& Henry E. Smith, The Property/Contract Interface, 101 Colum. L. Rev. 773 (2001). Also, potential purchasers of settlements are a select and expert audience. See Henry E. Smith, The Language of Property: Form, Context, and Audience Design, 55 Stan. L. Rev. (forthcoming Apr. 2003).

See Robert W. Wood, Taxation of Damage Awards and Settlement Payments 357, 361-66 (2d. ed. 1998) (discussing constructive receipt).
} 
not but it is not entirely clear at this time ${ }^{54}$-would likely interfere with the purpose of the structured settlement option in the first place. This would be especially so if the idea of subsidizing the plaintiff's decision to accept a structured settlement, rather than mandating it, reflects an effort to promote self-paternalism while minimizing the effect on the plaintiff's autonomy. ${ }^{55}$ The danger of plaintiffs losing their role is all the greater because defendants are often repeat players. ${ }^{56}$

Furthermore, after the injury the plaintiff and defendant are locked into a bilateral monopoly, and there is a danger that the defendant will capture the tax benefit of the structured settlement. Practitioners are unabashed about promoting the virtues of structured settlements as providing benefits for both sides and thus making settlement easier. ${ }^{57}$ Ironically, the U.S. government was among the large self-insured defendants who sought to capture for themselves the benefits of the tax exclusion of the growth in the annuity funding a structured settlement. ${ }^{58}$ Although it is conceivable that

${ }^{54}$ Richard B. Risk, Jr., Structured Settlements: The Ongoing Evolution from a Li-
ability Insurer's Ploy to an Injury Victim's Boon, 36 Tulsa L.J. 865, 894 \& n.149
$(2001)$.
${ }_{55}$ Relatedly, under the economic benefit doctrine, one must include in income a fund in which one's rights have vested (become nonforfeitable), see Sproull v. Commissioner, 16 T.C. 244 (1951), aff'd, 194 F.2d 541 (6th Cir. 1952), but this has been overridden by the Code and Regulations, see 26 C.F.R. $\$ 1.468 B-1$ (c)(2) (2002). See generally, Risk, supra note 54, at 895 (arguing that the economic benefit doctrine does not apply to qualified settlement funds because "[i]t is well settled in law that, when a statute or regulation is more current and more specific, the statute or regulation overrides the common law").

${ }^{56}$ Professor Pryor discusses the dangers to plaintiffs' role in the decisionmaking over settlements. Pryor, supra note 1 , at 1792-1813.

${ }^{57}$ See, e.g., Barbara D. Goldberg \& Kenneth Mauro, Utilizing Structured Settlements, in Evaluating and Settling a Personal Injury Case: Plaintiffs' and Defendants' Perspectives 2000, at 13, 20-21 (PLI Litig. \& Admin. Practice Course, Handbook Series No. H0-006K, 2000) ("Ideally, the tax savings on this investment [funding the structured settlement] over time could be split between the plaintiff and the defendant thereby resulting in a savings to both litigants. Or, in other words, for less money the plaintiff could receive a larger benefit. This would benefit both sides!").

${ }^{58}$ Richard Risk quotes from a Memorandum from Jeffrey Axelrad, Director, Torts Branch, Civil Division, U.S. Department of Justice, to Federal Torts Claims Act ("FTCA") Staff, Assistant United States Attorneys, and Agency Counsel, (May 10, 2000), which says:

The ability of a tax-free lifetime series of annuity payments, for example, should not be conferred on a plaintiff without an offsetting benefit to the government: that is, an adequate quid pro quo. You should be aware of all of the govern- 
Congress would provide a subsidy for settlement, there is little evidence of such a purpose and it is unclear that such a purpose would focus on personal injury litigation or require spread-out payments.

Not only is it less than clear that the tax subsidy was meant to promote settlement, but there is also a potential negative impact on deterrence if the defendant captures the tax benefit. If the defendant can capture a tax benefit resulting in lower expected liability, the incentive to take care will be reduced. ${ }^{59}$ Even if one could identify contexts in which tort law is over-deterring, subsidizing structured settlements would seem a very clumsy way of addressing that problem, especially since it makes the deterrent depend more than ever on the bargaining power of the defendant. Thus, the constructive receipt doctrine along with bilateral monopoly (and possible defendant repeat play) tend to mean that the tax subsidy for structured settlements is capturable by the defendant, which reduces deterrence, encourages capture efforts, and does not serve the self-paternalism-encouraging purpose of the subsidy.

A minimal solution to these problems would be to make the plaintiff's higher-level choice very clear when the settlement is being worked out. Where the public is in on the deal, defaults can be used to allow plaintiffs to choose benefits with strings attached or no benefits. Then, the chosen deal can be enforced, for example by taxing factoring transactions that are inconsistent with the plaintiff's choice (and not taxing otherwise) ${ }^{60}$ The clearer the menu, the

ment's interests and take them into account when you negotiate a settlement on behalf of the United States.

Risk, supra note 54, at 872 n.27. Professor Risk notes that the federal government's insistence on getting a reduction in the overall amount it spends on a settlement to offset the plaintiff's tax benefits under Section 130 of the Tax Code "appears to be in direct conflict with congressional intent as expressed in the Joint Committee on Taxation document, which considers the tax benefit a 'subsidy' designed to encourage the injury victim to accept periodic payments." Id.

Compare this to the collateral source rule, under which a plaintiff can collect from a defendant without reduction for compensation from insurers or other nondefendant third parties. Making the defendant pay for the full harm is required by deterrence. See David D. Haddock et al., An Ordinary Economic Rationale for Extraordinary Legal Sanctions, 78 Cal. L. Rev. 1, 44-45 (1990).

${ }^{60}$ Alternatively, one might try to recapture the benefits of the tax subsidy to the plaintiff by taxing the plaintiff, but this is likely to be more difficult than an excise tax on the transaction. For a summary of existing recapture rules in the Tax Code and a proposal for their use in household taxation, see Henry E. Smith, Intermediate Filing in Household Taxation, 72 S. Cal. L. Rev. 145, 191-92 \& n.167 (1998). 
less we have to worry about being paternalistic rather than merely enforcing self-paternalism of the plaintiff's choosing.

Further, if we take the tax subsidy for structured settlements seriously, then the constructive receipt doctrine should not be pressed so far that it can become a weapon in the hands of sophisticated defendants. Particularly in an era when self-settled spendthrift trusts seem to be arriving on the scene, it makes little sense to enforce such heavy restrictions on tort victims, who have not even chosen to be in the position of having the (higher-order) choice of mechanism for settlement payment.

Finally, a reflexive policy of promoting "alienability" of all intangible property rights should be rethought. We can promote higher-order contracting by allowing plaintiffs to contract away their ability to change (alienate) the structured settlement once it is set up. Again, this requires that plaintiffs-at the time of judgment-have information about the alternatives. If so, the apparent restriction on alienation is a freely chosen one, as part of an implicit bargain in return for a tax subsidy.

\section{CONCLUSION}

Structured settlements are structures of rights in which the Tax Code subsidizes certain self-paternalistic choices by plaintiffs. When one keeps in mind that the decisions here operate on multiple levels, it is clear how legal effort should be directed at the appropriate level in order to maximize the chance that plaintiffs will be provided for, that the public will not need to intervene further, and that defendants will face the correct deterrent prices and sanctions in their activity decisions. 